Article

\title{
Preparation and Application of Starch/Polyvinyl Alcohol/Citric Acid Ternary Blend Antimicrobial Functional Food Packaging Films
}

\author{
Zhijun Wu ${ }^{1}$, Jingjing $\mathrm{Wu}^{2}$, Tingting Peng ${ }^{2}$, Yutong $\mathrm{Li}^{2}$, Derong Lin ${ }^{2, *}$, Baoshan Xing ${ }^{3, *}$, \\ Chunxiao Li ${ }^{2}$, Yuqiu Yang ${ }^{2}$, Li Yang ${ }^{2}$, Lihua Zhang ${ }^{1}$, Rongchao Ma ${ }^{1}$, Weixiong Wu ${ }^{1}$, \\ Xiaorong $\mathrm{Lv}^{2}$, Jianwu Dai ${ }^{2}$ and Guoquan Han ${ }^{2}$ \\ 1 School of Mechanical and Electrical Engineering, Sichuan Agricultural University, Ya'an 625014, China; \\ wzj@sicau.edu.cn (Z.W.); 13908160316@163.com (L.Z.); 13608265802@163.com (R.M.); \\ 13350568176@163.com (W.W.) \\ 2 School of Food Science, Sichuan Agricultural University, Ya'an 625014, China; 13350966938@126.com (J.W.); \\ 18227590905@126.com (T.P.); 18227553959@126.com (Y.L.); 18227592524@126.com (C.L.); \\ 13822267735@126.com (Y.Y.); 18227591911@126.com (L.Y.); 13795853723@163.com (X.L.); \\ 18728187200@163.com (J.D.); dahan980306@126.com (G.H.) \\ 3 Stockbridge School of Agriculture, University of Massachusetts, Amherst, MA 01003, USA \\ * Correspondence: lindr2018@sicau.edu.cn (D.L.); bx@umass.edu (B.X.); Tel.: +86-835-288-2311 (D.L.)
}

Academic Editor: Helmut Schlaad

Received: 9 February 2017; Accepted: 10 March 2017; Published: 14 March 2017

\begin{abstract}
Ternary blend films were prepared with different ratios of starch/polyvinyl alcohol (PVA)/citric acid. The films were characterized by field emission scanning electron microscopy (FE-SEM), thermogravimetric analysis, as well as Fourier transform infrared (FTIR) analysis. The influence of different ratios of starch/polyvinyl alcohol (PVA)/citric acid and different drying times on the performance properties, transparency, tensile strength (TS), water vapor permeability (WVP), water solubility (WS), color difference $(\Delta \mathrm{E})$, and antimicrobial activity of the ternary blends films were investigated. The starch/polyvinyl alcohol/citric acid $\left(\mathrm{S} / \mathrm{P} / \mathrm{C}^{1: 1: 0}, \mathrm{~S} / \mathrm{P} / \mathrm{C}^{3: 1: 0.08}\right.$, and $S / P / C^{3: 3: 0.08}$ ) films were all highly transparent. The $S / P / C^{3: 3: 0.08}$ had a 54.31 times water-holding capacity of its own weight and its mechanical tensile strength was $46.45 \mathrm{MPa}$. In addition, its surface had good uniformity and compactness. The $S / P / C^{3: 1: 0.08}$ and $S / P / C^{3: 3: 0.08}$ showed strong antimicrobial activity to Listeria monocytogenes and Escherichia coli, which were the food-borne pathogenic bacteria used. The freshness test results of fresh figs showed that all of the blends prevented the formation of condensed water on the surface of the film, and the $S / P / C^{3: 1: 0.08}$ and $\mathrm{S} / \mathrm{P} / \mathrm{C}^{3: 3: 0.08}$ prevented the deterioration of figs during storage. The films can be used as an active food packaging system due to their strong antibacterial effect.
\end{abstract}

Keywords: packaging films; antimicrobial; figs (Ficus carica L.)

\section{Introduction}

Food packaging is an important part of food products, both to protect food quality and safety of food products to enhance their added value. Food packaging materials with sufficient mechanical strength, barrier properties, thermal stability, biodegradability, and antibacterial and antioxidant properties are necessary for food safety and extending the shelf life of packaged foods. Currently, the materials used in packaging industries are dominated by petroleum based plastic materials produced from fossil fuels since they are relatively cheap and convenient to use with good process capability and durability [1]. However, due to the non-biodegradable nature of petroleum-based plastics, the environmental pollution caused by traditional plastic packaging is becoming more and 
more serious, and thus there is a need to develop new packaging materials. With the development of modern biotechnology, biodegradable films as environmentally friendly materials are being paid increasing attention, and have become a new generation of hot research and development projects as well as becoming a part of the basic strategy included in a global economic sustainable development [2]. Natural polymer materials such as starch, which are biodegradable products, are renewable resources with low cost and great potential advantages. However, their poor barrier properties, mechanical and processability, compared to petroleum-based plastic materials, are a major limitation in the use of biopolymer films for food packaging applications. Generally, natural polymers are used to blend with nanomaterials or other synthetic polymers with the aim of extending their applications [1]. Currently, the mechanical, barrier, and antibacterial properties of the composite films compounded of nanomaterials and other materials such as silver, $\mathrm{ZnO}, \mathrm{TiO}_{2}$, are being studied by a variety of laboratory techniques and film coating methods. However, nanomaterials have not been widely used in industry. Poly (vinyl alcohol) (PVA) is a biodegradable synthetic polymer, which is a kind of thin film material with excellent performance and wide application. The combination of PVA and starch improved the degradation of starch-filled biodegradable plastic [3]. In addition, the research results on the composite film of polyvinyl alcohol (PVA) with a variety of materials, including essential oils, modified nano-materials etc., proved its good packaging performance, and the existence of film pores and the size of the loading affect the amount of antimicrobial agents, thus affecting the antibacterial properties of the film [4-9]. The use of biopolymers as substitutes for non-degradable traditional plastics is an interesting alternative still for short-term applications. In order to improve the fresh-keeping performance, the antibacterial property of the films is very necessary. Until now, the research status of antibacterial biodegradable cling films was as follows: As early as 1997, Zhao et al. found that $\mathrm{TiO}_{2}$ had a photocatalytic capacity, for the micro-organisms and toxins produced by decomposition. After that, photocatalytic antimicrobial agents began to develop rapidly [10]. At present, environmentally friendly films that incorporate organic contaminants into ordered mesoporous materials have been used in food packaging [11-15]. In addition, through the analysis of ginger oil, thyme oil, grapefruit, peach leaf extract and so on, it was found that the essential oil had antibacterial effect, and proved that the prepared plastic wrap could save the food to achieve the effect of preservation and antibacterial [14,16-18].

Recently, there have been many studies on figs, the subjects of this experiment, such as the life cycle and nutritive value of figs, the changes of physiological and storage quality, the effects of different storage temperature, the effects of different packaging materials and the effect of 1-MCP treatment on the storage quality of figs [19-23]. The results showed that the figs have high nutritional value, good antibacterial, antifungal and anti-cancer activities as well as others [24,25]. In previous work, citric acid was added to the film, the different characteristics of film preservation were analyzed, and their antibacterial and biodegradability were discussed [26,27]. However, due to the few reports that have been made on films with high mechanical and thermal properties, the preparation of PVA/starch based biodegradable antibacterial films has practical significance and is of great significance in the field of food packaging. Therefore, the purpose of the present study is to use starch and polyvinyl alcohol composite, modified to obtain films with better antibacterial, mechanical, and thermal properties, to prepare PVA/starch based citric acid biodegradable antimicrobial films.

\section{Materials and Methods}

\subsection{Materials}

Citric acid, (Tianjin Bodi Chemical Co., Ltd., Tianjin, China); corn starch, food grade, (Zhuhai Jindu Tide Food Co., Ltd., Zhuhai, China); glycerol, analytical pure, (Wuxi Yatai United Chemical Co., Ltd., Wuxi, China); polyvinyl alcohol (Shanghai Yingjia Industrial Chemical Co., Ltd., Shanghai, China); distilled water, (laboratory homemade). 
DZKW-D-1 electric heating thermostatic water bath (Zhengzhou North and South Instrument Co., Ltd., Henan, China); FA2204B analytical balance (Guangzhou Ruiming Instrument Co., Ltd., Guangzhou, China); TWCL-T electronic thermostat (Shanghai Branch equipment Co., Ltd., Shanghai, China); JJ YZG/FZG vacuum dryer (Changzhou Nile Drying Equipment Co., Ltd., Changzhou, Jiangsu, China); WDW-20 computer controlled electronic universal testing machine (Beijing Dana Machinery Co., Ltd., Beijing, China); $\mathrm{CH}-1-\mathrm{B}$ hand count (Shanghai music magnetic instrument company, Shanghai, China); Thermogravimetric analyzer (Leco TGA 701; Leco, St Joseph, MI, USA); FE-SEM (LINE No. 337, 338, S-4800) [Hitachi Co., Ltd., Matsuda, Japan]; ATR FT-IR, (Billerica, MA, USA).

\subsection{Preparation of Films}

Starch/Polyvinyl alcohol (S/P) ternary blend functional food packaging films were prepared by using the solvent casting method [28]. Film solution were prepared by dissolving $2.81 \mathrm{~g}$ of starch, polyvinyl alcohol into $30 \mathrm{~mL}$ of distilled water with $2.11 \mathrm{~g}$ of glycerol as a plasticizer while mixing vigorously for about $45 \mathrm{~min}$ at $95^{\circ} \mathrm{C}$ using an electric stirrer. The $\mathrm{S} / \mathrm{P}$ and citric acid composite films (S/P/C) were prepared by the solution casting method as described by Wang et al. [28]. First, PVA was dissolved in distilled water at $95^{\circ} \mathrm{C}$ while the corn starch was gelatinized at $90^{\circ} \mathrm{C}$. Thereafter, citric acid was added to the PVA solution at $80^{\circ} \mathrm{C}$, gelatinized starch and glycerin were added with stirring for $30 \mathrm{~min}$. A transparent and uniform film fluid was obtained.

All the film solutions were cast onto leveled glass plate $(25 \mathrm{~cm} \times 25 \mathrm{~cm})$ and were dried for about $24 \mathrm{~h}$ at room temperature and peeled off from the plate to obtain a dried film. The film thickness was measured using a micrometer (40SH/SD, Mahr, Goettigen, Germany) with an accuracy of $0.01 \mathrm{~mm}$. All films samples were preconditioned in a constant temperature humidity chamber set at $25 \%$ and $50 \% \mathrm{RH}$ for at least $48 \mathrm{~h}$ before further testing (Table 1 ).

Table 1. Test design of composition.

\begin{tabular}{|c|c|c|c|c|c|}
\hline Film & Polyvinyl Alcohol (g) & Starch (g) & Glycerol (g) & Citric Acid (g) & Baking Time (min) \\
\hline $\mathrm{S} / \mathrm{P} / \mathrm{C}^{1: 1: 0}$ & 2.81 & 2.81 & 1.87 & 0 & 120 \\
\hline $\mathrm{S} / \mathrm{P} / \mathrm{C}^{3: 3: 0.08}$ & 2.81 & 2.81 & 2.11 & 1 & 120 \\
\hline $\mathrm{S} / \mathrm{P} / \mathrm{C}^{3: 1: 0.08}$ & 3.75 & 1.25 & 2.5 & 1 & 120 \\
\hline $\mathrm{S} / \mathrm{P} / \mathrm{C}^{1: 1: 0}$ & 2.81 & 2.81 & 1.87 & 0 & 270 \\
\hline $\mathrm{S} / \mathrm{P} / \mathrm{C}^{3: 3: 0.08}$ & 2.81 & 2.81 & 2.11 & 1 & 270 \\
\hline $\mathrm{S} / \mathrm{P} / \mathrm{C}^{3: 1: 0.08}$ & 3.75 & 1.25 & 2.5 & 1 & 270 \\
\hline$S / P / C^{1: 1: 0}$ & 2.81 & 2.81 & 1.87 & 0 & 300 \\
\hline$S / P / C^{3: 3: 0.08}$ & 2.81 & 2.81 & 2.11 & 1 & 300 \\
\hline $\mathrm{S} / \mathrm{P} / \mathrm{C}^{3: 1: 0.08}$ & 3.75 & 1.25 & 2.5 & 1 & 300 \\
\hline
\end{tabular}

\subsection{Surface Color and Transparency of Films}

The surface color of the films was measured using a white color plate $(L=97.75, a=-0.49$, and $b=1.96$ ) as a standard background for color measurement [29]. Total color difference (DE) was calculated as follows:

$$
\Delta E=\left[(\Delta L)^{2}+(\Delta a)^{2}+(\Delta b)^{2}\right]^{0.5}
$$

$\Delta L$ means bright and dark, + is bright, - indicates darkness; $\Delta a$ for red and green, + for reddish, and for partial green; $\Delta b$ represents yellow and blue, + indicates yellowish, - indicates blue.

\subsection{Surface Morphology and FTIR Analysis}

The films were cut to a size of $1 \mathrm{~mm} \times 4 \mathrm{~mm}$. The surfaces of the films were fixed with conductive adhesive and were sprayed with gold. The composite films were observed using a field FE-emission scanning electron microscopy (FE-SEM (LINE No. 337, 338), S-4800, Hitachi Co., Ltd., Matsuda, Japan) 
operated at an acceleration voltage of $1 \mathrm{kV}$ [29]. By using Spectrum 100 Fourier transform infrared spectroscopy (FT-IR), spectroscopy analysis was performed and the three kinds of films tested with a KBr tablet [30]. The analysis conditions of the different starch composite film samples ATR-FTIR all had a scanning frequency of 128 with spectral resolution of $4 \mathrm{~cm} \sim(-1)$ where the wave-number ranged from 4000 to $400 \mathrm{~cm}^{-1}$.

\subsection{Mechanical Properties}

The mechanical properties of the films were analyzed by measuring the tensile strength (TS) and elongation at break $(E)$ according to the standard ASTM method D 882-88 using an Instron Universal Testing Machine (Model MDX, Instron Engineering Corporation, Canton, MA, USA) equipped with a $0.5 \mathrm{kN}$ load cell. Each film was cut into rectangular strips $(3 \mathrm{~cm} \times 8 \mathrm{~cm})$. The machine was operated in tensile mode with an initial grip separation of $50 \mathrm{~mm}$ and crosshead speed of $50 \mathrm{~mm} / \mathrm{min}$. The TS was determined by dividing the maximum load $(N)$ by the initial cross-sectional area $\left(\mathrm{m}^{2}\right)$ of the films and expressed in MPa. The $E(\%)$ was determined by dividing the extension at rupture of the films by the initial length of the films $(50 \mathrm{~mm})$ multiplied by 100 [28].

Each sample was tested three times and averaged. Then the TS of the films was calculated using the following equation:

$$
T_{S}=\frac{F}{S}
$$

In the formula:

Ts - Tensile strength, MPa;

F-The maximum tensile force when the sample breaks, $\mathrm{N}$;

$S$-Cross-sectional area of specimen, $\mathrm{m}^{2}$.

\subsection{Water Vapor Permeability (WVP)}

The water vapor transmission rate (WVP) of films was determined gravimetrically at $25^{\circ} \mathrm{C}$ under $50 \%$ RH conditions using water vapor transmission measuring cups in accordance with the ASTM E96-95 standard method. Each sample was measured five times [31]. Then, the WVP of the films was calculated using the following Equation (3):

$$
\mathrm{WVP}=\frac{W V T R \times n \times K}{\triangle p}
$$

In the formula:

WVP-Water vapor transmission coefficient, $\times 10^{-9} \mathrm{~g} \cdot \mathrm{m} /\left(\mathrm{m}^{2} \cdot \mathrm{Pa} \cdot \mathrm{s}\right)$;

WVTR - The amount of water vapor transmitted through the instrument was measured, $\mathrm{g} /(\mathrm{m} \cdot \mathrm{d})$;

$n$-Film thickness, mm;

$\Delta p$-The output pressure of the gas is $0.20 \mathrm{MPa}$.

\subsection{Determination of Solubility of Cling Film References}

When the dissolution rate was measured, the films $(20 \mathrm{~mm} \times 20 \mathrm{~mm})$ were dried in a constant temperature blast oven at $70{ }^{\circ} \mathrm{C}$ for $24 \mathrm{~h}$ and taken as the initial weight of the films [28]. The films were then placed in $100 \mathrm{~mL}$ of deionized water and were taken out after $24 \mathrm{~h}$ to dry off surface moisture. The remaining films were placed in a constant temperature blast oven at $70^{\circ} \mathrm{C}$ for $24 \mathrm{~h}$ to obtain the weight of the final films, $\mathrm{mt}$. The dissolution rate is calculated according to the equation:

$$
D=\frac{\left(m_{0}-m_{t}\right)}{m_{0}} \times 100 \%
$$


In the formula:

$D$-Dissolution rate, \%;

$M_{0}$-Initial film weight, $\mathrm{g}$.

\subsection{Thermal Stability}

The thermal stability of film samples was evaluated using a thermogravimetric analyzer (Leco TGA701; Leco, St Joseph, MI, USA). About $25 \mathrm{mg}$ of film sample was taken in a standard aluminum cup and heated from 25 to $600{ }^{\circ} \mathrm{C}$ with a heating rate of $12{ }^{\circ} \mathrm{C} / \mathrm{min}$ under a nitrogen flow $\left(50 \mathrm{~cm}^{3} / \mathrm{min}\right)$. An empty cup was taken as a reference. The derivative form of TGA (DTG) was obtained by calculating the differentials of the TGA values using a central finite difference method as follows:

$$
\mathrm{DTG}=\frac{\left(W_{t+\Delta t}-W_{t+\Delta t}\right)}{2 \Delta t}
$$

where $W_{t+\Delta t}-W_{t-\Delta t}$ are the residual weight of sample at time $t+\Delta t$ and $t-\Delta t$, respectively, and $\Delta t$ is the time interval for reading the residual sample weight [32].

\subsection{Antibacterial Activity}

The antibacterial activities of $\mathrm{S} / \mathrm{P} / \mathrm{C}^{1: 1: 0}, \mathrm{~S} / \mathrm{P} / \mathrm{C}^{3: 1: 0.08}$, and $\mathrm{S} / \mathrm{P} / \mathrm{C}^{3: 3: 0.08}$ films were examined for their inhibitory effects against the growth of Gram-positive bacteria, L. monocytogenes, and Gram-negative bacteria, E. coli. L. monocytogenes. E. coli were aseptically inoculated in $20 \mathrm{~mL}$ BHI (brain infusion) and TSB (trypsin soy broth) broth, respectively and subsequently incubated at $37^{\circ} \mathrm{C}$ for $15 \mathrm{~h}$. Each cultured broth was centrifuged at $4000 \mathrm{rpm}$ for $10 \mathrm{~min}$ and the cell pellets were suspended in $100 \mathrm{~mL}$ of sterile TSB and BHI broth respectively, and diluted 10 times with sterile distilled water. Then $50 \mathrm{~mL}$ of diluted broth $\left(10^{6} \mathrm{e} 10^{7} \mathrm{CFU} / \mathrm{mL}\right)$ was taken into $100 \mathrm{~mL}$ of the conical flask containing films sample $(5 \mathrm{~cm} \times 5 \mathrm{~cm})$ and subsequently incubated at $37{ }^{\circ} \mathrm{C}$ for $12 \mathrm{~h}$ under mild shaking. The same diluted broth without film sample was used as the control. At every $3 \mathrm{~h}$ interval, the cell viability of each pathogen was calculated by absorbance value which was determined at $600 \mathrm{~nm}$ with a spectrophotometer. Antimicrobial tests were performed in triplicate with individually prepared films [28].

\subsection{Packaging Test}

The figs were wrapped with plastic wrap and the physiological indexes were measured.

\subsubsection{Determination of Malondialdehyde (MDA) Content}

Take $1 \mathrm{~g}$ of the fig in a bowl with $10 \mathrm{~mL}$ of Tris- $\mathrm{HCl}$ buffer $\left(0.1 \mathrm{~mol} \cdot \mathrm{L}^{-1} \mathrm{pH} 8.5\right)$ added and then mix well and grind into a homogenate. All the homogenate is transferred into a centrifuge tube and centrifuged at $4000 \mathrm{rpm}\left(4^{\circ} \mathrm{C}\right)$ for $5 \mathrm{~min}$. An amount of $1.5 \mathrm{~mL}$ of the supernatant is used (The control group is added with $1.5 \mathrm{~mL}$ of $10 \%$ TCA solution) with $2.5 \mathrm{~mL}$ of $0.5 \%$ TBA solution added, mixed up and then reacted in boiling water for $15 \mathrm{~min}$, rapidly cooled down and then centrifuged (if clear supernatant no need to centrifuge). The supernatant was measured for absorbance at wavelengths of 450,532 , and $600 \mathrm{~nm}$ with a spectrophotometer.

$$
M D A\left(\mu \mathrm{mol} \cdot \mathrm{FW} \cdot \mathrm{g}^{-1}\right)=\left[6.45 \times\left(O D_{532}-O D_{600}\right)-0.56 \times O D_{450}\right] \times V \times \frac{V_{1}}{V_{2}} \times M
$$

$V$-Volume of extract, $\mathrm{mL}$;

$V_{1}$-Volume of reaction, $\mathrm{mL}$;

$V_{2}$-Determined volume of extract, $\mathrm{mL}$;

$M-F r e s h$ weight of plant tissue, $\mathrm{g}$. 


\subsubsection{Determination of Ascorbic Acid Content}

Grind the fig into a homogenate, take $15 \mathrm{~g}$ in a $100 \mathrm{~mL}$ volumetric flask, add $1 \%$ oxalic acid to the scale line and then filter with absorbent cotton. Take $10 \mathrm{~mL}$ of the filtrate, place it into a $100 \mathrm{~mL}$ beaker, and add $1 \mathrm{~mL}$ of $1 \%$ starch and $20 \mathrm{~mL}$ of $1 \%$ oxalic acid. Mix them and titrate to blue with standard iodine keeping $15 \mathrm{~s}$ without fading, write down the date. Do three parallel experiments and take the average, also do a blank test.

$$
X=\frac{H \times\left(V_{1}-V_{2}\right)}{M} \times 100
$$

$X-\mathrm{mg}$ of ascorbic acid per $100 \mathrm{~g}$ of figs, $\mathrm{mg} /(100 \mathrm{~g})$;

$\mathrm{H}$-Concentration of standard iodine, $\mathrm{mg} / \mathrm{mL}$;

$V_{1}$-Consumption of standard iodine titration volume, $\mathrm{mL}$;

$V_{2}$-Consumption of standard iodine solution volume by blank titration, $\mathrm{mL}$;

$M-$ Quality of the sample, g.

\subsubsection{Determination of Reducing Sugar Content}

Take $10 \mathrm{~g}$ homogenate of the fig, transfer into a $250 \mathrm{~mL}$ volumetric flask, slowly add $5 \mathrm{~mL}$ of zinc acetate solution and $5 \mathrm{~mL}$ of potassium ferrocyanide solution, dilute with water to the mark, shake it and let it stand for $30 \mathrm{~min}$. Filter with a dry filter, discard the early filtrate and collect the filtrate in a $250 \mathrm{~mL}$ conical flask in reserve.

Accurately draw $5 \mathrm{~mL}$ each of the basic copper tartrate solution A and B into a $100 \mathrm{~mL}$ conical flask, add $10 \mathrm{~mL}$ of distilled water and 3 pieces of glass beads. Then add $9 \mathrm{~mL}$ standard glucose solution $(1 \mathrm{~mol} / \mathrm{L})$ into the conical flask and heat to boil in $2 \mathrm{~min}$. Add a standard glucose solution until the blue solution just fades. Do three parallel experiments to obtain the average.

$$
F=C \times V
$$

F-10 $\mathrm{mL}$ of basic copper tartrate solution corresponds to the mass of glucose, $\mathrm{mg}$;

C-Concentration of standard glucose solution, $\mathrm{mg} / \mathrm{mL}$;

$V$-The volume of the standard glucose solution consumed during calibration, $\mathrm{mL}$.

Determination of the sample solution: Take $5 \mathrm{~mL}$ each of the basic copper tartrate solution A and B, place them in a $100 \mathrm{~mL}$ conical flask and then add $10 \mathrm{~mL}$ distilled water and 3 pieces of glass beads. Add the sample to the burette and add to the boiling solution until the blue solution just fades at the end. Carry out three times to obtain the average.

$$
X=\frac{F}{M \times \frac{V}{250} \times 1000} \times 100
$$

$X-\mathrm{mg}$ of reducing sugar per $100 \mathrm{~g}$ of figs, $\mathrm{mg} /(100 \mathrm{~g})$;

$M$-Weight of sample, g; F-10 mL of basic copper tartrate solution corresponds to the mass of glucose, mg;

$V$-The volume of the sample solution consumed in the assay, $\mathrm{mL}$;

250-Total volume of sample solution, $\mathrm{mL}$.

\subsubsection{Determination of Titratable Acid Content}

Take $20 \mathrm{~g}$ of homogenate (accurate to $0.001 \mathrm{~g}$ ), place in $250 \mathrm{~mL}$ volumetric flask, dilute with water to the mark. Hold it for $30 \mathrm{~min}$ and shake 2 or 3 times during this time. Filter with absorbent cotton and collect the filtrate in a $250 \mathrm{~mL}$ conical flask in reserve.

Take $20 \mathrm{~mL}$ of the filtrate in the conical flask, add 2 drops of phenolphthalein indicator, titrate to pink color with calibrated $\mathrm{NaOH}$ solution $(0.011 \mathrm{~mol} / \mathrm{L})$ for $30 \mathrm{~s}$ without fading and record the amount 
of $\mathrm{NaOH}$ solution. Do three parallel experiments for every sample to obtain the average, and carry out a blank test.

$$
X=\frac{C \times\left(V_{1}-V_{2}\right) \times K}{M} \times 100
$$

$X$-Number of grams of acid per $100 \mathrm{~g}$ of figs, $\mathrm{g} /(100 \mathrm{~g})$;

C-Concentration of sodium hydroxide standard titration solution, $\mathrm{mol} / \mathrm{L}$;

$V_{1}$-The volume of the standard sodium hydroxide solution consumed, $\mathrm{mL}$;

$V_{2}$-The volume of the standard sodium hydroxide solution consumed in the blank experiment, in $\mathrm{mL}$;

$K-$ Conversion factor of acid, 0.067 in malic acid;

$M$-Weight of sample, g.

\subsubsection{Determination of Polyphenols}

There are many methods for the determination of polyphenols, but we decided to use high performance liquid chromatography (HPLC) in consideration of the experimental devices and other factors. In addition, it was necessary to prepare ferrous tartrate solution: Weigh $1 \mathrm{~g}$ of ferrous sulfate and $5 \mathrm{~g}$ of potassium sodium tartrate, dissolve in water and make up to $1 \mathrm{~L}$ (the liquid was stored overnight before use and can be stable for 1 week).

Accurately weigh $1 \mathrm{~g}$ of grated figs in a $250 \mathrm{~mL}$ beaker, add $80 \mathrm{~mL}$ of boiling water, hold in boiling water for $30 \mathrm{~min}$ and then filter the liquid in the beaker, wash, transfer the filtrate into a $100 \mathrm{~mL}$ volumetric flask. The liquid is cooled to room temperature and finally diluted to the scale line with distilled water, and shaken evenly. Take $1 \mathrm{~mL}$ of the sample solution into a $25 \mathrm{~mL}$ volumetric flask, add $4 \mathrm{~mL}$ of distilled water, $5 \mathrm{~mL}$ of ferrous tartrate solution in order, shake, and then add the phosphate buffer ( $\mathrm{pH}=7.5)$ to the scale line. The sample solution is replaced without ferrous tartrate solution as a blank experiment. The absorbance values are determined at a wavelength of $540 \mathrm{~nm}$ with a colorimetric cup of $5 \mathrm{~cm}$.

$$
P=A \times \frac{7.826}{1000} \times \frac{V_{1}}{V_{2} \times m} \times 100 \%
$$

$P$-Content of polyphenols, $\mathrm{g} / 100 \mathrm{~mL}$;

A-Absorbance of sample solution;

$V_{1}$-Total sample solution, $\mathrm{mL}$;

$V_{2}$-The amount of test solution taken, $\mathrm{mL}$;

$M-$ Quality of sample, g.

\subsubsection{Determination of the Activity of Catalase (CAT)}

Take one gram of figs (Chengdu, China) for pre-cooling, add $20 \mathrm{~mL}$ of phosphate buffer $(\mathrm{pH}=7.8)$, grind into slurry in an ice bath, transfer it into a $25 \mathrm{~mL}$ volumetric flask and then flush the portland with the buffer. Add the phosphate buffer to the scale line and put the volumetric flask in the fridge at $5{ }^{\circ} \mathrm{C}$.

Let it stand for $10 \mathrm{~min}$. Next, put it into a centrifugal tube and centrifuge at $4000 \mathrm{r} / \mathrm{min}\left(4{ }^{\circ} \mathrm{C}\right)$ for $15 \mathrm{~min}$. Preserve the supernatant at the low temperature. The reaction system consists of $2.9 \mathrm{~mL}$, $20 \mathrm{~mol} / \mathrm{L}$ of $\mathrm{H}_{2} \mathrm{O}_{2}$ and $0.1 \mathrm{~mL}$ of the supernatant with distilled water as blank control. Begin to record after $15 \mathrm{~s}$ from the start of the reaction. Absorbance is measured at a wavelength of $240 \mathrm{~nm}$ and the data taken as the initial data. Record a data point every $30 \mathrm{~s}$ and it is necessary to measure continuously to obtain six data. Carry out three parallel experiments. Take the reducing absorbance of 0.01 per gram of sample per minute as a unit of the catalase's activity. The unit is $0.01 \Delta \mathrm{OD} 240 \mathrm{~min}^{-1} \cdot \mathrm{g}^{-1}$ fresh weight (FW). 


\subsection{Statistical Analysis}

Films properties were measured with individually prepared films in triplicate, as the replicated experimental units and the results were provided with mean \pm SD (standard deviation) values. One-way analysis of variance (ANOVA) was performed, and the significance of each mean property value was determined $(p<0.05)$ with the Duncan's multiple range test of the statistical analysis system using the SPSS computer program (SPSS, Inc., Chicago, IL, USA).

\section{Results and Discussion}

\subsection{Apparent Color and Optical Properties of Films}

All the film solutions for the preparation of $S / P / C^{1: 1: 0}, S / P / C^{3: 1: 0.08}$, and $S / P / C^{3: 3: 0.08}$ formed uniform and standing films. Apparently, the $\mathrm{S} / \mathrm{P} / \mathrm{C}^{3: 3: 0.08}$ was clear and transparent with high lightness (high Hunter L-value of 71.2) as shown in Table 2. The $\mathrm{S} / \mathrm{P} / \mathrm{C}^{3: 10.08}$ and $\mathrm{S} / \mathrm{P} / \mathrm{C}^{3: 3: 0.08}$ composite films maintained high transparency with slight decrease in lightness and the slight increase in yellowness as shown in the decreased Hunter-b values, respectively. The increase in yellow tint of the $S / P / C^{3: 1: 0.08}$ and $\mathrm{S} / \mathrm{P} / \mathrm{C}^{3: 3: 0.08}$ composite films was mainly attributed to the polyphenols compounds included in the citric acid [33].

Table 2. Test of the color differences of starch/polyvinyl alcohol/citric acid ternary blend functional food packaging films.

\begin{tabular}{ccccc}
\hline Film & $\boldsymbol{\Delta} \mathbf{L}(\mathbf{N B S})$ & $\boldsymbol{\Delta a}(\mathbf{N B S})$ & $\boldsymbol{\Delta} \mathbf{b}(\mathbf{N B S})$ & $\Delta \mathbf{E}(\mathbf{N B S})$ \\
\hline Without cover & $39.690 \pm 0.0035$ & $5.603 \pm 0.0008$ & $-17.503 \pm 0.0002$ & $43.740 \pm 0.0028$ \\
S/P/C $1: 1: 0$ & $62.490 \pm 0.0010$ & $5.613 \pm 0.0028$ & $-17.943 \pm 0.0002$ & $65.260 \pm 0.0009$ \\
S/P/C $3: 3: 0.08$ & $71.200 \pm 0.0012$ & $5.860 \pm 0.0062$ & $-18.453 \pm 0.0047$ & $73.790 \pm 0.0012$ \\
S/P/C $3: 1: 0.08$ & $54.707 \pm 0.0006$ & $5.680 \pm 0.0012$ & $-17.273 \pm 0.0010$ & $57.653 \pm 0.0004$ \\
S/P/C $1: 1: 0$ & $66.053 \pm 0.0032$ & $6.020 \pm 0.0044$ & $-17.890 \pm 0.0011$ & $68.687 \pm 0.0031$ \\
S/P/C $3: 3: 0.08$ & $67.617 \pm 0.0014$ & $5.627 \pm 0.0052$ & $-17.963 \pm 0.0002$ & $70.190 \pm 0.0013$ \\
\hline
\end{tabular}

Each value is the mean of three replicates with the standard deviation, Any two means in the same column followed by the same letter are not significantly $(p>0.05)$ different by Duncan's multiple range tests.

\subsection{Microstructure and Fourier Transform Infrared (FTIR) Analysis}

Microstructure of the films was evaluated using FE-SEM and the resulting FE-SEM images of surface morphology of the films are shown in Figure 1. The FE-SEM images of the films showed that all the films had a uniform and smooth surface. As can be seen from the surface topography of the films, the surfaces are homogeneous, smooth, and continuous, no pores appear, and the surfaces of the films are continuous and dense. The white granular material may be starch granules, and the starch granules will reduce the mechanical properties. $\mathrm{S} / \mathrm{P} / \mathrm{C}^{3: 1: 0.08}$ and $\mathrm{S} / \mathrm{P} / \mathrm{C}^{3: 3: 0.08}$ showed that the surfaces of the composite films were free of projections and wrinkles, and the phase separation interface between PVA and starch was not significant. This indicates that glycerol and citric acid can significantly improve the binding of starch and polyvinyl alcohol and enhance the dense homogeneity of the film. FE-SEM images of the control and cross-linked films do not show any appreciable change in surface morphology due to cross-linking, as seen from Figure 1 . The $S / P / C^{3: 1: 0.08}$ and $S / P / C^{3: 3: 0.08}$ were homogenous without pores or cracks and the starch molecules had been well dispersed without the many granules that were observed in films made from starch mixed with PVA.

FTIR analysis of the films was carried out to study the interactions between fillers and polymer matrix and the resulting FTIR spectra are shown in Figure 2. The absorption peak observed at $3391 \mathrm{~cm}^{-1}$ is related to the stretching vibration of $\mathrm{O}-\mathrm{H}$ in the starch and PVA structures [33-35]. The peaks at $1779 \mathrm{~cm}^{-1}$ correspond to the carboxyl and ester carbonyl bands [36]. The spectra of $S / P / C^{3: 3: 0.08}$ and $S / P / C^{3: 1: 0.08}$ films shows that the peak band increases and the peak intensity increased compared with the $S / P / C^{1: 1: 0}$ film. The intensity of the band increases and the values of 
the peak band migrate from 3391 to $3536 \mathrm{~cm}^{-1}$, from 1779 to $1760 \mathrm{~cm}^{-1}$, and from 1563 to $1513 \mathrm{~cm}^{-1}$. The results show that the characteristic absorption peaks are consistent with the relative published results [32]. These changes may be related to starch, glycerol, PVA content of different ratios, and the addition of citric acid modifies PVA, resulting in modified PVA with starch association enhanced.

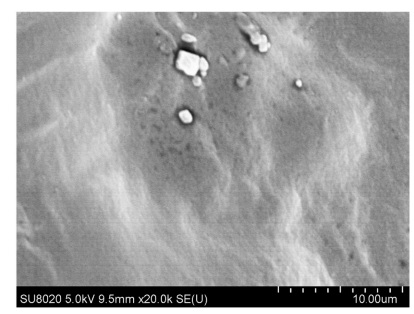

$\mathrm{S} / \mathrm{P} / \mathrm{C}^{1: 1: 0}$

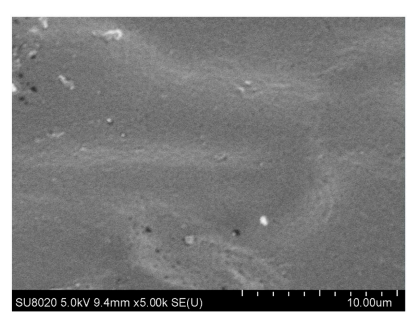

$\mathrm{S} / \mathrm{P} / \mathrm{C}^{3: 1: 0.08}$

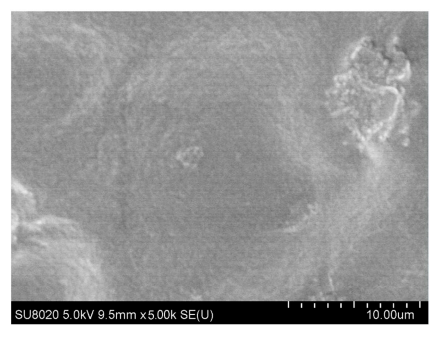

$\mathrm{S} / \mathrm{P} / \mathrm{C}^{3: 3: 0.08}$

Figure 1. FE-SEM images of starch/polyvinyl alcohol/citric acid ternary blend functional food packaging films.

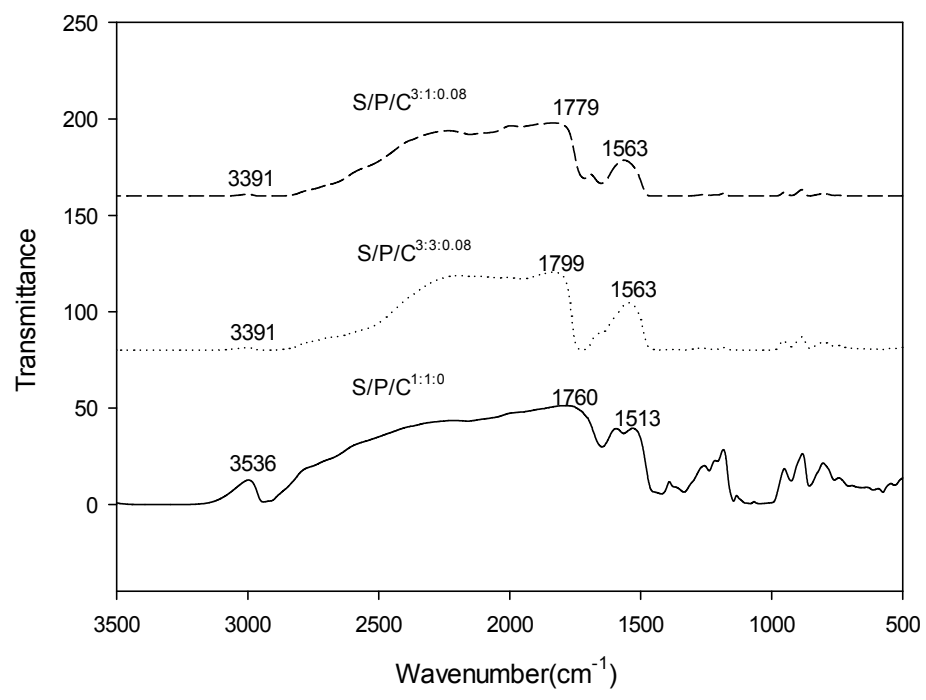

Figure 2. FTIR spectra of starch/polyvinyl alcohol/citric acid ternary blend functional food packaging films.

\subsection{Mechanical Properties}

Mechanical properties such as tensile strength (TS), elongation at break (E), of the $\mathrm{S} / \mathrm{P} / \mathrm{C}^{1: 1: 0}$ blend films are shown in Table 3. Thickness of the $S / P / C^{3: 1: 0}$ and $S / P / C^{3: 3: 0.08}$ blend films increased slightly by the addition of citric acid, which is mainly due to the increased solid content. The TS, which indicates the strength of film, of the $\mathrm{S} / \mathrm{P} / \mathrm{C}^{1: 1: 0}$ control films was $35.98 \pm 1.8 \mathrm{MPa}$. Although 
the strength of the $\mathrm{S} / \mathrm{P} / \mathrm{C}^{3: 3: 0.08}$ films was lower than that of the agar/carrageenan/konjac ternary blend film prepared with a similar method as the present study [37], it was comparable to those of commodity plastic films such as high density polyethylene (22-23 MPa), low density polyethylene (19-44 MPa), and polypropylene (31-38 MPa) [38]. The optimum baking time for each of the three films was $270 \mathrm{~min}$. However, as time increased to 300 minutes, a long bake caused the films to crack, resulting in a sharp drop in TS. Yet, compared with the $\mathrm{S} / \mathrm{P} / \mathrm{C}^{1: 1: 0}$ films, the TS of the composite films with citric acid added was significantly increased $(p<0.05)$, including the $\mathrm{S} / \mathrm{P} / \mathrm{C}^{3: 3: 0.08}$ and the $\mathrm{S} / \mathrm{P} / \mathrm{C}^{3: 1: 0.08}$. The increase of mechanical strength is mainly due to the physical attraction between the polymer matrix PVA and citric acid, and the polycarboxylation of citric acid with the alcoholic hydroxyl groups of PVA, as shown by FTIR results. The distribution of citric acid with high elastic modulus generate tremendous interfacial contacts with the polymer matrices, which leads to effective stress transfer resulting in an increase in the TS [37]. On the contrary, the flexibility of $S / P / C^{3: 3: 0.08}$ composite films decreased slightly while that of $\mathrm{S} / \mathrm{P} / \mathrm{C}^{3: 1: 0.08}$ composite films increased slightly compared with the control $\mathrm{S} / \mathrm{P} / \mathrm{C}^{1: 1: 0}$ blend film, as indicated by the $\mathrm{E}$ values. The $\mathrm{E}$ of a film is usually inversely proportional to the TS of the films as shown in the present study. The slight increase of flexibility (i.e., increase in $\mathrm{E}$ ) of the $\mathrm{S} / \mathrm{P} / \mathrm{C}^{3: 10.08}$ composite films can be attributed to the higher amount of glycerol (a plasticizer) accompanied by the citric acid. Glycerol acts as a plasticizer without forming any covalent linkages with the biopolymer. The hydroxyl groups present in glycerol are expected to form hydrogen bonds with the biopolymer molecules at the carbonyl and hydroxyl sites. Being small in size, this effectively increases the free volume of the system, thus decreasing the glass transition temperature and intermolecular forces. As a result, the plasticized biopolymer matrix changes from brittle to leathery to rubber with increased flexibility and extensibility of the film. Manufacturer's information indicated that the citric acid contained $30 \%$ of glycerol.

Table 3. Tensile properties of starch/polyvinyl alcohol/citric acid ternary blend functional food packaging films.

\begin{tabular}{cccc}
\hline Film & Thickness $(\mathbf{m m})$ & Tensile Strength $(\mathbf{M P a})$ & Elastic Modulus (\%) \\
\hline S/P/C $1: 1: 0$ & $0.0606 \pm 0.0277$ & $33.84 \pm 1.8$ & $27 \pm 2.5$ \\
S/P/C $3: 3: 0.08$ & $0.0648 \pm 0.0691$ & $45.22 \pm 2.4$ & $66 \pm 3.6$ \\
S/P/C $3: 1: 0.08$ & $0.1150 \pm 0.0139$ & $19.58 \pm 1.1$ & $27 \pm 5.1$ \\
S/P/C $1: 1: 0$ & $0.0688 \pm 0.0674$ & $35.98 \pm 2.5$ & $29 \pm 4.8$ \\
S/P/C $3: 3: 0.08$ & $0.1220 \pm 0.0250$ & $45.54 \pm 2.6$ & $74 \pm 2.4$ \\
S/P/C $3: 1: 0.08$ & $0.1074 \pm 0.0327$ & $23.25 \pm 1.5$ & $31 \pm 2.1$ \\
S/P/C $1: 1: 0$ & $0.0538 \pm 0.0416$ & $34.51 \pm 2.3$ & $27 \pm 2.0$ \\
S/P/C $3: 3: 0.08$ & $0.0694 \pm 0.0276$ & $31.68 \pm 2.0$ & $36 \pm 3.1$ \\
S/P/C $3: 1: 0.08$ & $0.1166 \pm 0.0402$ & $20.00 \pm 2.7$ & $21 \pm 2.4$ \\
\hline
\end{tabular}

Each value is the mean of three replicates with the standard deviation, Any two means in the same column followed by the same letter are not significantly $(p>0.05)$ different by Duncan's multiple range tests.

\subsection{Water Vapor Permeability (WVP)}

The WVP of the $\mathrm{S} / \mathrm{P} / \mathrm{C}^{1: 1: 0}$ was determined by a gravimetric method using WVP cups and the results are shown in Table 4 . The WVP value of the control films was $(1.56 \pm 0.09) \times 10^{-9} \mathrm{~g} \mathrm{~m} / \mathrm{m}^{2} \cdot \mathrm{Pa} \cdot \mathrm{s}$ which is comparable to the usual carbohydrate biopolymer films [37]. While the WVP of $S / P / C^{3: 1: 0.08}$ composite films was not significantly different from that of the control $\mathrm{S} / \mathrm{P} / \mathrm{C}^{1: 1: 0}$ blend films, that of $\mathrm{S} / \mathrm{P} / \mathrm{C}^{3: 3: 0.08}$ composite film decreased significantly $(p<0.05)$ compared with the control film. Such decrease in the WVP has been frequently observed with other biopolymers composited with citric acid [37,39]. The starch nanocrystals obtained by removing the amorphous parts of the original starch granules by acid hydrolysis under the gelatinization temperature are compact, have high rigidity, high crystallinity, and low moisture permeability due to their disc shape. When starch paste was added dropwise to PVA, the starch reassembled with polymerization to form nanoprecipitation by intermolecular or intramolecular hydrogen bond interaction. This is probably due to the fact that the 
starch nanocrystals are susceptible to forming a well intercalated nanocomposite structure and form nano-precipitates with the modified organic citric acid which acts as a reinforcing agent to modify the polyvinyl alcohol. Thus, the permeability of the water vapor due to the permeability of the starch/PVA nanoparticles leads to twists and turns $[28,35]$. The water solubility of $\mathrm{S} / \mathrm{P} / \mathrm{C}^{1: 1: 0}$ was high, because its main components were starch and polyvinyl alcohol cross-linked polymer. The results are shown in Table 4. The addition of citric acid resulted in the films cross-linking more closely, and the S/P/C with the same ratio of starch and polyvinyl alcohol had better water solubility. On the contrary, the water soluble effect of $S / P / C^{3: 3: 0.08}$ was worse than that of $S / P / C^{3: 100.08}$, because it had a large amount of PVA, which did not have the cross-linking effect. Citric acid can thus enhance the water solubility of the film.

Table 4. The water vapor permeation rate and solubility of starch/polyvinyl alcohol/citric acid ternary blend functional food packaging films.

\begin{tabular}{ccc}
\hline Film & WVP $\left(\times \mathbf{1 0}^{-\mathbf{9}} \mathbf{g} \cdot \mathbf{m} / \mathbf{m}^{\mathbf{2}} \cdot \mathbf{P a} \cdot \mathbf{s}\right)$ & Water Solubility (\%) \\
\hline $\mathrm{S} / \mathrm{P} / C^{1: 1: 0}$ & $1.15 \pm 0.04$ & $29.8 \pm 0.5$ \\
$\mathrm{~S} / \mathrm{P} / \mathrm{C}^{3: 3: 0.08}$ & $1.21 \pm 0.05$ & $41.1 \pm 0.2$ \\
$\mathrm{~S} / \mathrm{P} / \mathrm{C}^{3: 1: 0.08}$ & $0.36 \pm 0.11$ & $6.5 \pm 0.12$ \\
$\mathrm{~S} / \mathrm{P} / \mathrm{C}^{1: 1: 0}$ & $1.56 \pm 0.09$ & $36.1 \pm 0.04$ \\
$\mathrm{~S} / \mathrm{P} / \mathrm{C}^{3: 3: 0.08}$ & $1.95 \pm 0.15$ & $45.6 \pm 0.3$ \\
$\mathrm{~S} / \mathrm{P} / \mathrm{C}^{3: 1: 0.08}$ & $0.42 \pm 0.08$ & $7.0 \pm 0.7$ \\
$\mathrm{~S} / \mathrm{P} / \mathrm{C}^{1: 1: 0}$ & $1.64 \pm 0.10$ & $33.5 \pm 0.2$ \\
$\mathrm{~S} / \mathrm{P} / \mathrm{C}^{3: 3: 0.08}$ & $1.76 \pm 0.03$ & $40.9 \pm 0.14$ \\
$\mathrm{~S} / \mathrm{P} / \mathrm{C}^{3: 1: 0.08}$ & $0.21 \pm 0.13$ & $6.2 \pm 0.6$ \\
\hline
\end{tabular}

\subsection{Thermal Stability}

The films were tested for their thermal stability using a thermogravimetric analyzer (TGA), and the resulting TGA curves are shown in Figure 3. The derivative thermogravimetric analysis (DTG) curves are shown in Figure 4. The thermo-gravimetric curves show that the films with decreasing weight and the DTGA curves show the maximum decomposition temperature (T max) of thermal decomposition [40]. The films exhibited multi-step thermal decomposition.

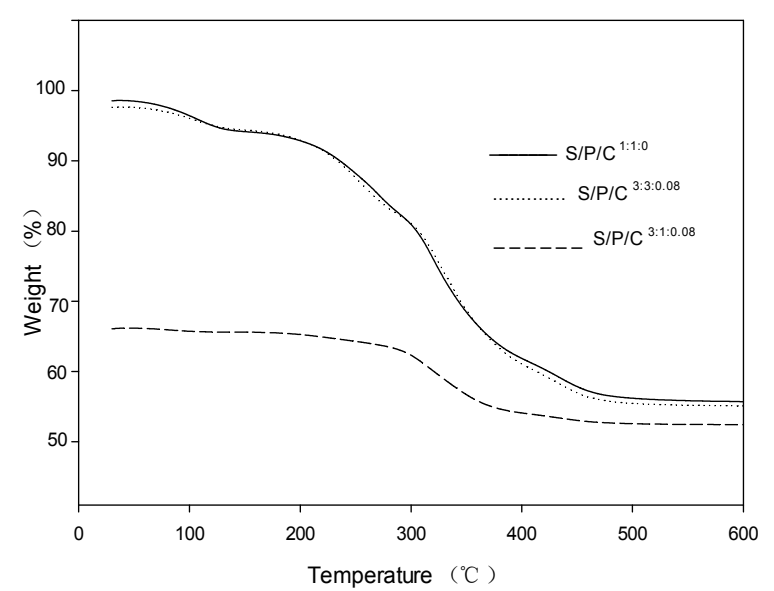

Figure 3. TGA thermograms of starch/polyvinyl alcohol/citric acid ternary blend functional food packaging films. 


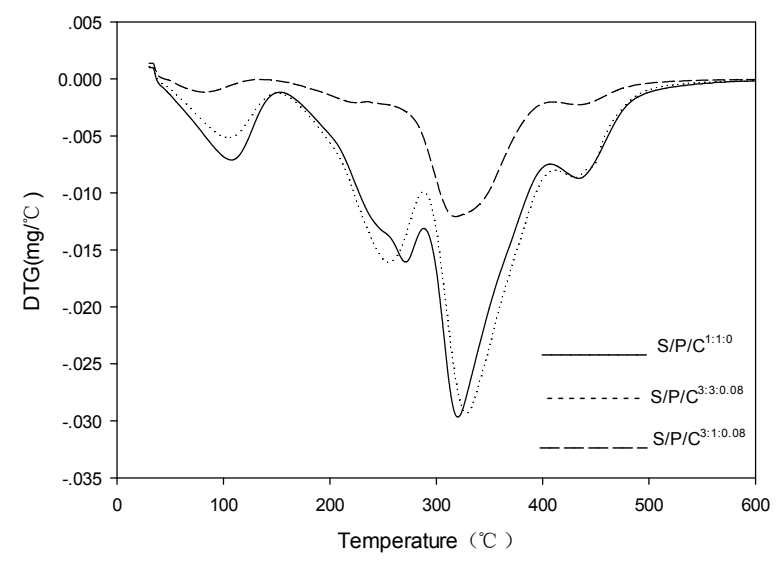

Figure 4. DTG thermograms of starch/polyvinyl alcohol/citric acid ternary blend functional food packaging films.

The initial thermal decomposition of the $\mathrm{S} / \mathrm{P} / \mathrm{C}^{1: 1: 0}$ was observed from $90-105^{\circ} \mathrm{C}$, which was due to evaporation of water, weight loss of $2.490 \mathrm{mg}$, accounting for $10.24 \%$ of the total mass of the sample, and then the main thermal decomposition was observed in the range of $200-320{ }^{\circ} \mathrm{C}$ with the maximum decomposition rate around $310^{\circ} \mathrm{C}$, weight loss $22.395 \mathrm{mg}$, accounting for $88.118 \%$ of the total mass of the sample, which is due to starch and PVA molecules through hydrogen bonding formed by the new structure of thermal decomposition. Residuals left after the final thermal destruction at $600{ }^{\circ} \mathrm{C}$ were $52.149 \%, 57.025 \%$, and $57.121 \%$ for the $\mathrm{S} / \mathrm{P} / \mathrm{C}^{3: 1 ; 0.08}, \mathrm{~S} / \mathrm{P} / \mathrm{C}^{3: 3: 0.08}$, and $\mathrm{S} / \mathrm{P} / \mathrm{C}^{1: 1: 0}$ films, respectively. The $\mathrm{S} / \mathrm{P} / \mathrm{C}^{3: 3: 0.08}$ was initially observed from $90-110{ }^{\circ} \mathrm{C}$, due to water evaporation, weight loss of $1.7589 \mathrm{mg}, 7.387 \%$ of the total mass of the sample, and then the major thermal decomposition to the maximum decomposition rate observed in the $200-320{ }^{\circ} \mathrm{C}$ range with the maximum decomposition rate around $320^{\circ} \mathrm{C}$, weight loss $21.234 \mathrm{mg}$, accounting for $89.180 \%$ of the total mass of the sample, which is due to the modification of PVA by citric acid. This makes the starch and modified PVA molecules through hydrogen bonding form more new structure thermal decomposition [38].

Thus, the cross-linking between the modified PVA and the starch becomes more compact due to the addition of citric acid to the polyvinyl alcohol, and the stability of the films is enhanced [35].

\subsection{Antimicrobial Activity}

The antibacterial activities of the ternary blends films and blank control groups against Gram-positive (L. monocytogenes) and Gram-negative (E. coli) food-borne pathogenic bacteria are shown in Figure 5. As expected, the $\mathrm{S} / \mathrm{P} / \mathrm{C}^{1: 1: 0}$ films did not show any antimicrobial activity against test organisms, but the concentration of bacteria compared to the blank control group was even larger while the two others with citric acid added exhibited strong antimicrobial activity against both Gram-positive (L. mono-cytogenes) and Gram-negative (E. coli) bacteria. In general, the effect of $\mathrm{S} / \mathrm{P} / \mathrm{C}^{3: 3: 0.08}$ was more pronounced than that of $S / P / C^{3: 1: 0.08}$. It has been shown that the antibacterial mechanism of organic acid antibacterial agents is mainly to combine with the cell membrane of bacteria to break down the synthesis system between protein and cell membrane, so as to inhibit the propagation of bacteria. On the other hand, Gram-positive bacteria (L. mono-cytogenes) was more susceptible to the citric acid-included films than Gram-negative bacteria (E. coli). In addition, citric acid possesses acidity so that citric acid-added films have anti-bacterial properties, which is well-known [41]. 

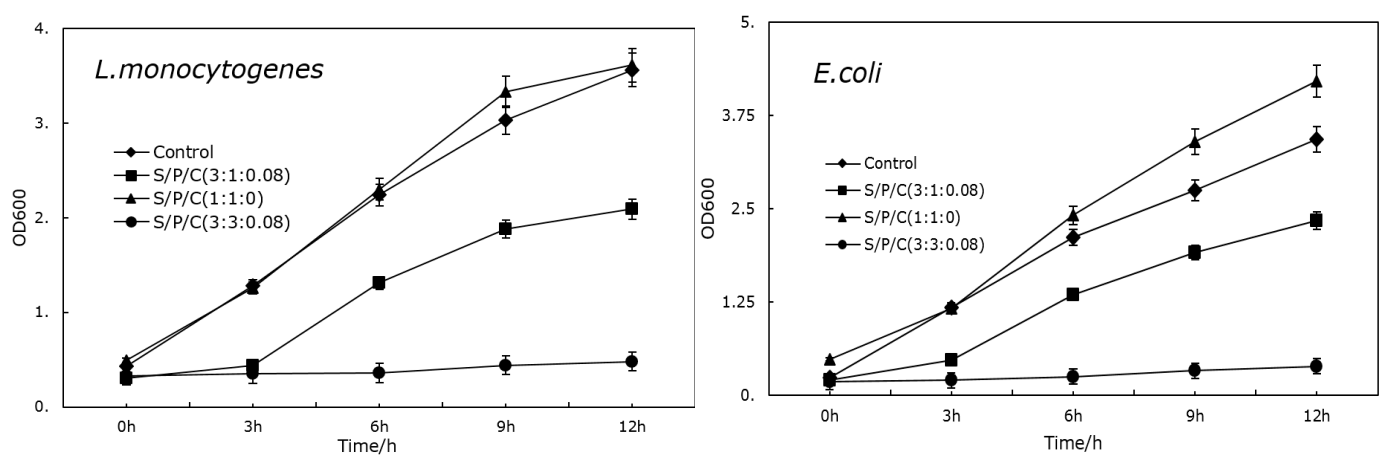

Figure 5. Antimicrobial activity of degradable antibacterial film against foodborne pathogenic bacteria, L. monocytogenes and E. coli.

\subsection{Packaging Test}

\subsubsection{Effect of Degradable Antibacterial Films on Titratable Acid (TA) Content during Storage}

The results (Figure 6) revealed that the titratable acid (TA) content of the figs (Ficus carica L.) steadily increased during the first seven days of the storage. Thereafter, the titratable acid content gradually decreased. Organic acids in figs mainly include citric acid and tartaric acid, they not only can be used as respiratory matrix, which is the main source of synthetic energy ATP, but also a provider of many intermediate metabolites required for intracellular biochemical processes. As a result, the titratable acid is continuously consumed as a respiratory substrate [42-44]. There are researches that show there is a decrease in TA values as a natural tendency of the maturation process $[45,46]$. However, the titratable acid content of figs which were stored with $\mathrm{S} / \mathrm{P} / \mathrm{C}^{3: 3: 0.08}$ was obviously higher compared to that of the others throughout the storage period. Thus, the effect of $\mathrm{S} / \mathrm{P} / \mathrm{C}^{3: 3: 0.08}$ was more effective than the other types.

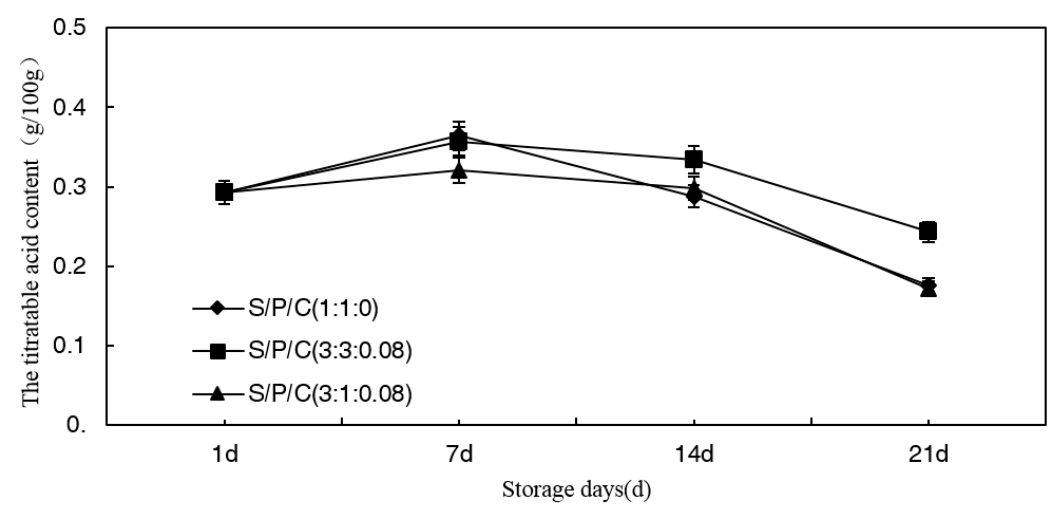

Figure 6. Effect of starch/polyvinyl alcohol/citric acid ternary blend functional food packaging films on the TA.

\subsubsection{Effect of Degradable Antibacterial Films on Ascorbic Acid Content during Storage}

Ascorbic acid, as an antioxidant and anti-aging agent, is an essential nutrient for the human body. The ascorbic acid content can affect the fresh flavor and nutritional quality of fruits and vegetables, so it is often used as an important indicator when measuring the quality of fruits and vegetables [47]. The data presented in Figure 7 clearly show that a climacteric-like peak in the ascorbic acid content was observed in the figs on the seventh day, after that time, the ascorbic acid content gradually decreased. However, $\mathrm{S} / \mathrm{P} / \mathrm{C}^{3: 1: 0.08}$ had the best effect on delaying the reduction of the ascorbic acid content, followed by $\mathrm{S} / \mathrm{P} / \mathrm{C}^{3: 3: 0.08}$. Thus, citric acid can prevent browning as well as inhibit the decline in ascorbic acid content. Similar findings were also reported by Jiang et al. and Santerre et al. in 
fruits $[48,49]$. There were some differences in the delay of the reduction of the ascorbic acid between $\mathrm{S} / \mathrm{P} / \mathrm{C}^{3: 3: 0.08}$ and $\mathrm{S} / \mathrm{P} / \mathrm{C}^{3: 1: 0.08}$, which might be due to different levels of oxidation affected by the permeability of the films to atmospheric oxygen [50].

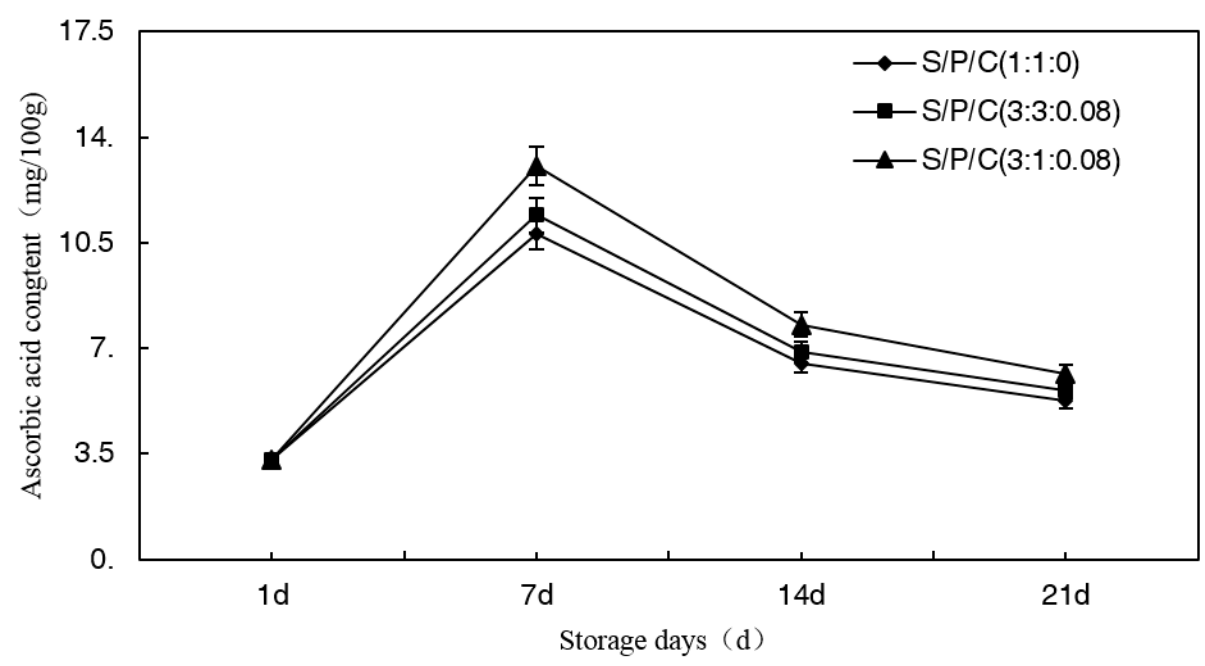

Figure 7. Effect of starch/polyvinyl alcohol/citric acid ternary blend functional food packaging films on ascorbic acid content during storage.

\subsubsection{Effect of Degradable Antibacterial Films on Reducing Sugar Content during Storage}

As the time of storage increased, the reducing sugar content of the figs decreased on the whole (Figure 8). However, the content stored with $\mathrm{S} / \mathrm{P} / \mathrm{C}^{3: 3: 0.08}$ increased until the 14th day of the storage and then rapidly decreased. Among the treatments, $S / P / C^{1: 1: 0}$ and $S / P / C^{3: 1: 0.08}$ had the highest values on the seventh day. On the 14 th day, $\mathrm{S} / \mathrm{P} / \mathrm{C}^{3: 3: 0.08}$ had the maximum value $(1.476 \mathrm{mg} / 100 \mathrm{~g})$. On the other hand, there were no significant differences between stored at $S / P / C^{3: 1: 0.08}$ and stored at $\mathrm{S} / \mathrm{P} / \mathrm{C}^{3: 1: 0.08}$ with the storage time increasing. In the early stage of storage, the figs showed full ripeness whose starch was decomposed completely, and then the content of reducing sugar increased slightly. In the later period of storage, most of the reducing sugars were consumed by the respiration of the figs, which resulted in a decrease in the reducing sugar content [51-53]. However, the effect of $\mathrm{S} / \mathrm{P} / \mathrm{C}^{3: 3: 0.08}$ on the delayed reducing sugar consumption was the best.

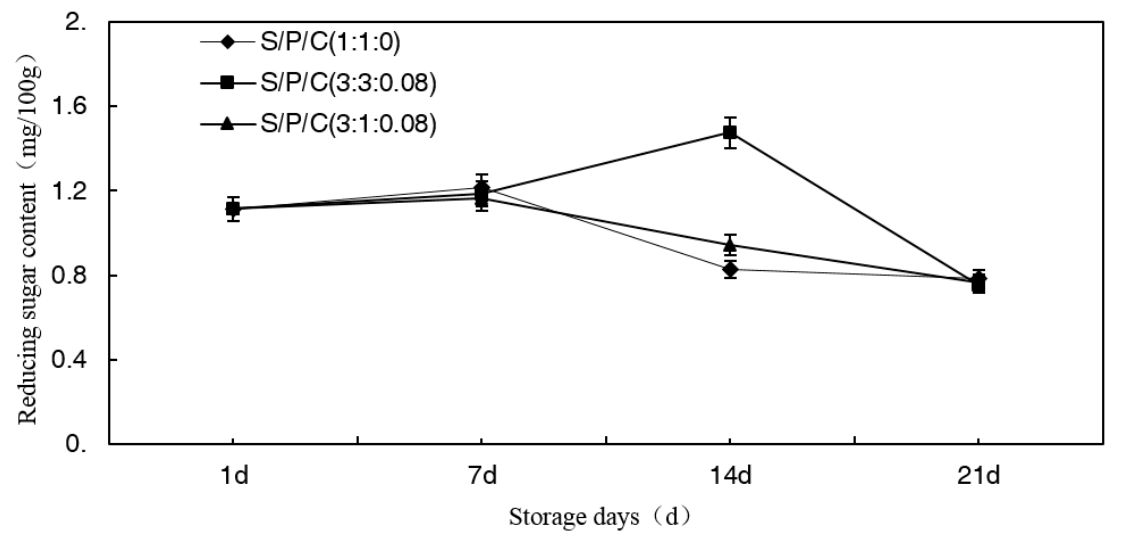

Figure 8. Effect of starch/polyvinyl alcohol/citric acid ternary blend functional food packaging films antibacterial and degradable film on reducing sugar. 


\subsubsection{Effect of Degradable Antibacterial Films on Polyphenol Content during Storage}

As time of storage increased, the polyphenol content of the figs decreased overall (Figure 9). Among the treatments, the three kinds of films showed that on the first day to the seventh day levels dropped fast and then reached the lowest values on the 14th day of the storage then keeping close to zero. There were no significant differences between the films and all had a minimal effect on polyphenol. In storage, the polyphenol content fell sharply in the first week as a result of the polyphenols' antioxidant functions which protected the cells from damage $[54,55]$.

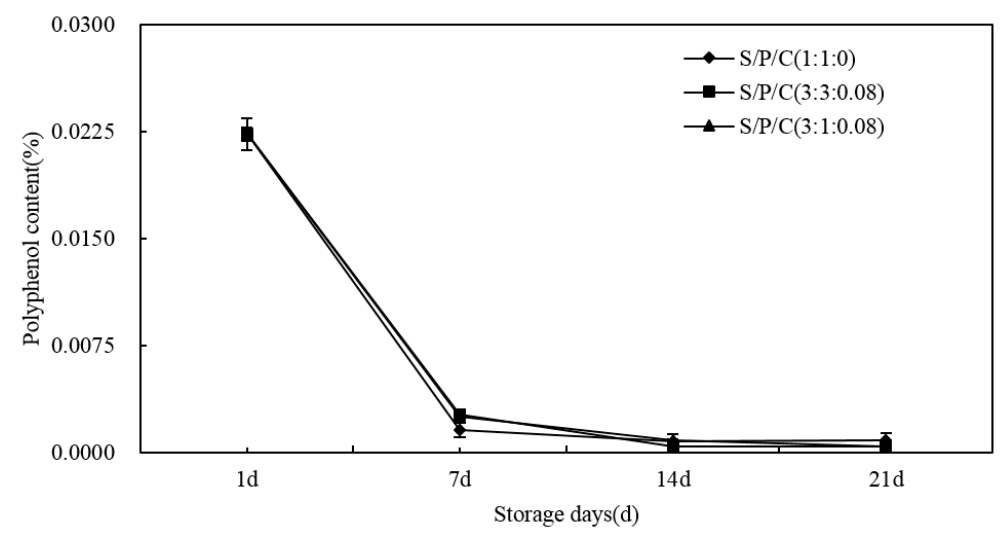

Figure 9. Effect of starch/polyvinyl alcohol/citric acid ternary blend functional food packaging films on the content of polyphenols.

\subsubsection{Effect of Degradable Antibacterial Films on CAT Content during Storage}

As time of storage increased, the CAT content of the figs increased after decreasing and reached the highest values on the seventh day of storage (Figure 10). CAT can act as a free radical scavenger to help remove free radicals, which play an important role in the activity of reactive oxygen species [56,57]. During the period of plants' maturity, the CAT content of the figs increases and then during the plants' senescence period, the CAT content of the figs decreases. The highest values of $S / P / C^{1: 1: 0}$, $\mathrm{S} / \mathrm{P} / \mathrm{C}^{3: 3: 0.08}$ and $\mathrm{S} / \mathrm{P} / \mathrm{C}^{3: 1: 0.08}$ were $0.014\left(0.01 \Delta \mathrm{OD} 240 \mathrm{~min}^{-1} \cdot \mathrm{g}^{-1}\right), 0.021\left(0.01 \Delta \mathrm{OD} 240 \mathrm{~min}^{-1} \cdot \mathrm{g}^{-1}\right)$, and $0.007\left(0.01 \Delta \mathrm{OD} 240 \mathrm{~min}^{-1} \cdot \mathrm{g}^{-1}\right)$ respectively. In conclusion, the $\mathrm{S} / \mathrm{P} / \mathrm{C}^{3: 3: 0.08}$ was more effective for CAT.

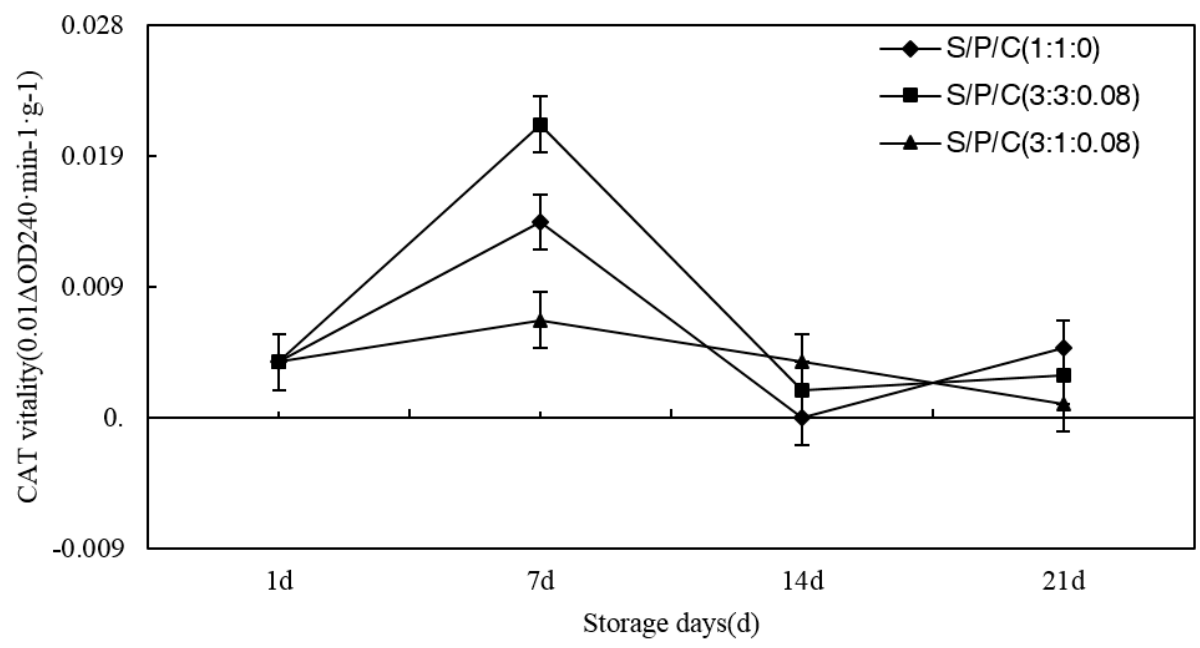

Figure 10. Effect of starch/polyvinyl alcohol/citric acid ternary blend functional food packaging films on the activity of CAT. 


\subsubsection{Effect of Degradable Antibacterial Films on MDA Content during Storage}

As time of storage increased, the reducing sugar content of the figs increased on the whole. The results revealed that the MDA content of the figs steadily increased during the storage (Figure 11). However, in comparison, the $\mathrm{S} / \mathrm{P} / \mathrm{C}^{1: 1: 0}$ had the fastest growth, the $\mathrm{S} / \mathrm{P} / \mathrm{C}^{3: 1: 0.08}$ increased slowly, and the $\mathrm{S} / \mathrm{P} / \mathrm{C}^{3: 3: 0.08}$ was the lowest. During the process of storage, MDA was used as a standard that assess the degree of oxidation and the capacity to resist environmental change [58]. Excessive MDA can cause oxidative deterioration of fresh figs. Citric acid is an antioxidant synergist that enhances the antioxidant resistance of the antioxidant, thereby reducing the reduction of MDA and the permeability of the membrane to maintain the freshness of the fig.

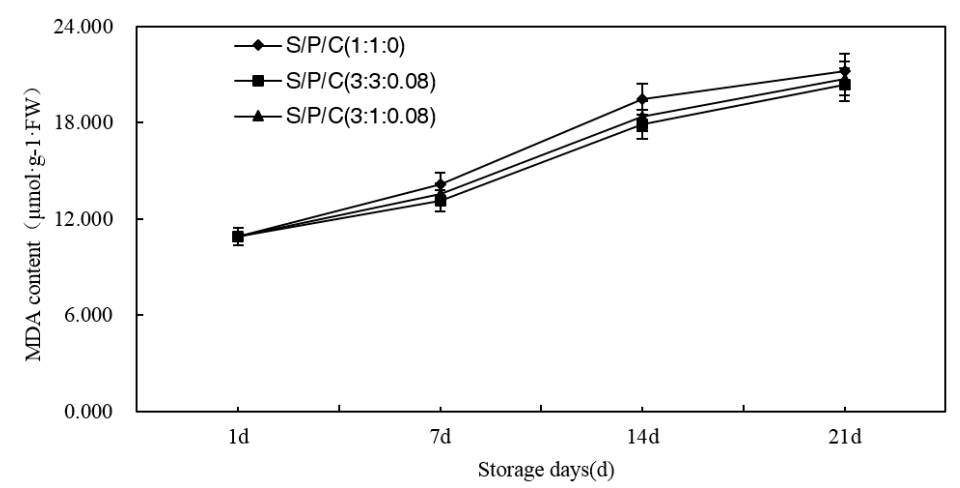

Figure 11. Effect of starch/polyvinyl alcohol/citric acid ternary blend functional food packaging films on the content of MDA.

\section{Conclusions}

Various composite films were prepared using different amounts of citric acid, different drying times, and different proportions of major components. When the concentration of citric acid in the mixed starch/PVA/citric acid composite film was 1.0\%, the calcination time was about $270 \mathrm{~min}$, and the tensile strength of the membrane was significant. In addition, the results of the fresh fig-packed test showed that citric acid-doped ternary blend film acids effectively prevented fruit from corrupting as well as preventing fogging on the surface due to its water vapor permeation function, and also proved ternary. The blend films have high water holding capacity and high water resistance. The $\mathrm{S} / \mathrm{P} / \mathrm{C}^{1: 1: 0}$ film did not show any antimicrobial activity against test organisms, but the concentration of bacteria compared to the blank control group was even larger while the two others with citric acid added exhibited strong antimicrobial activity against both Gram-positive (L. mono-cytogenes) and Gram-negative (E. coli) bacteria. In summary, the $\mathrm{S} / \mathrm{P} / \mathrm{C}^{3: 1: 0.08}$ and $\mathrm{S} / \mathrm{P} / \mathrm{C}^{3: 3: 0.08}$ composites have high potential for packaging highly breathable fresh agricultural products as antifogging packaging films and active food packaging systems due to their strong antibacterial (E. coli, Listeria) effect.

Acknowledgments: The authors thank the "211 Engineering Double Support Plan (No. 03572081)", Sichuan Agricultural University, and the education department of Sichuan Province major project for financial support.

Author Contributions: Derong Lin, Zhijun Wu, Jingjing Wu, and Baoshan Xing initiated the writing of this manuscript and designed the experiments of this manuscript, interpreted results, and drafted the manuscript. Tingting Peng, Chunxiao Li, and Yuqiu Yang collected and sorted out the references. Yutong Li, and Li Yang gave some valuable advice on the structure of the manuscript. Lihua Zhang, Rongchao Ma and Weixiong Wu compiled information and made contribution to the revision of the manuscript. Xiaorong Lv, Jianwu Dai, Guoquan Han, Hejun $\mathrm{Wu}$ made certain contribution to the language modification of the review.

Conflicts of Interest: The authors declare no conflict of interest. 


\section{References}

1. Shankar, S.; Teng, X.N.; Li, G.B.; Rhim, J.W. Preparation, characterization, and antimicrobial activity of gelatin/ZnO nanocomposite films. Food Hydrocoll. 2015, 45, 264-271. [CrossRef]

2. Sudesh, K.; Iwata, T. Sustainability of biobased and biodegradable plastics. Clean Soil Air Water 2008, 36, 433-442. [CrossRef]

3. Follain, N.; Joly, C.; Dole, P.; Bliard, C. Properties of starch based blends. Part 2. Influence of poly vinyl alcohol addition and photocrosslinking on starch based materials mechanical properties. Carbohydr. Polym. 2005, 60, 185-192. [CrossRef]

4. De Dicastillo, C.L.; Bustos, F.; Guarda, A.; Galotto, M.J. Cross-linked methyl cellulose films with murta fruit extract for antioxidant and antimicrobial active food packaging. Food Hydrocoll. 2016, 10, 335-344. [CrossRef]

5. Qin, Y.; Liu, D.; Wu, Y.; Yuan, M.; Li, L.; Yang, J. Effect of PLA/PCL/cinnamaldehyde antimicrobial packaging on physicochemical and microbial quality of button mushroom (agaricusbisporus). Postharvest Biol. Technol. 2015, 99, 73-79. [CrossRef]

6. Liu, Y.; Wang, X.; Yang, F.; Yang, X. Excellent antimicrobial properties of mesoporous anatase $\mathrm{TiO}_{2}$ and $\mathrm{Ag} / \mathrm{TiO}_{2}$ composite films. Microporous Mesoporous Mater. 2008, 114, 431-439. [CrossRef]

7. Quintavalla, S.; Vicini, L. Antimicrobial food packaging in meat industry. Meat Sci. 2002, 62, 373-380. [CrossRef]

8. Cano, A.; Cháfer, M.; Chiralt, A.; González-Martínez, C. Physical and antimicrobial properties of starch-pva blend films as affected by the incorporation of natural antimicrobial agents. Foods 2016, 5, 42-45. [CrossRef] [PubMed]

9. Virtanen, S.; Vartianen, J.; Setälä, H.; Tammelin, T.; Vuoti, S. Modified nanofibrillated cellulose-polyvinyl alcohol films with improved mechanical performance. RSC Adv. 2014, 4, 11343-11350. [CrossRef]

10. Appendini, P.; Hotchkiss, J.H. Review of antimicrobial food packaging. Innov. Food Sci. Emerg. 2002, 3, 113-126. [CrossRef]

11. Lin, D.R.; Hu, L.J.; Xing, B.S.; You, H.; Loy, D.A. Mechanisms of competitive adsorption organic pollutants on hexylene-bridged polysilsesquioxane(BPS). Materials 2015, 8, 5806-5817. [CrossRef]

12. Pranoto, Y.; Salokhe, V.M.; Rakshit, S.K. Physical and antibacterial properties of alginate-based edible film incorporated with garlic oil. Food Res. Int. 2005, 38, 267-272. [CrossRef]

13. Xu, W.; Qu, W.; Huang, K.; Guo, F.; Yang, J.; Zhao, H.; Luo, Y. Antibacterial effect of grapefruit seed extract on food-borne pathogena and its application in the preservation of minimally processed vegetables. Postharvest Biol. Technol. 2007, 45, 126-133. [CrossRef]

14. Tripathi, P.; Dubey, N.K.; Shukia, A.K. Use of essential oils as post-harvest botanical fungicides in the management of grey mould of grapes caused by Botrytis cinerea. World J. Microbiol. Biotechnol. 2008, 24, 39-46. [CrossRef]

15. Lin, D.R.; Hu, L.J.; You, H.; Williams, R.J.J. Synthesis and characterization of a nanostructured photoluminescent silsesquioxane containing urea and dodecyl groups that can be patterned on carbon films. Eur. Polym. J. 2011, 47, 1526-1533. [CrossRef]

16. Mehdizadeh, T.; Tajik, H.; Rohani, S.M.R.; Oromiehie, A.R. Antibacterial antioxidant and optical properties of edible starch-chitosan composite film containing thymus kotschyanus essential oil. Vet. Res. Forum 2012, 3, 167-173. [PubMed]

17. Masril, K.I. Antibacterial and antioxidant of uwi (dioscoreaalata L) starch edible film incorporated with ginger essential oil. Int. J. Biosci. Biochem. Bioinform. 2013, 3, 354-356.

18. Kusnadi, J.; Budyanto, P. Antibacterial active packaging edible film formulation with addition teak (tectonagrandis) leaf extract. Int. J. Life Sci. Biotechnol. Pharm. Res. 2015, 4, 79-84.

19. Vovlas, N.; Larizza, A. Relationship of schistonchuscaprifici (aphelenchoididae) with fig inflorescences, the fig pollinator Blastophagapsenes, and its cleptoparasitePhilotrypesiscaricae. Fund. Appl. Nematol. 1996, 19, 443-448.

20. Bucić-Kojić, A.; Planinić, M.; Tomas, S.; Jokić, S.; Mujić, I.; Bilić, M.; Velić, D. Effect of extraction conditions on the extractability of phenolic compounds from lyophilised fig fruits (ficuscarica L.). Pol. J. Food Nutr. Sci. 2011, 61, 195. 
21. Ozkaya, O.; ÇÖmlekÇioglu, S.; DemircioĞlu, H. Assessment of the potential of 1-methylcyclopropene treatments to maintain fruit quality of the common fig (ficuscarica L. cv. bursa siyahi) during refrigerated storage. Not. Bot. Horti Agrobot. 2014, 42, 516-522.

22. Bernalte, G.M.; Hernandez, M.T.; Lozano, R.M. Effect of temperature on the shelf-life of fig fruit during refrigerated storage. Acta Hortic. 2003, 6, 229-232. [CrossRef]

23. Gozlekci, S.; Erkan, M.; Karasahin, I.; Sahin, G. Effect of 1-methylcyclopropene (1-MCP) on fig (Ficuscarica cv. Bardakci) storage. Acta Hortic. 2008, 798, 325-330. [CrossRef]

24. Weibin, J.; Kai, M.; Zhifeng, L.; Yelin, W. The production and research of fig (Ficuscarica L.) in China. Acta Hortic. 2003, 6, 191-196.

25. Javed, A.; Iffat, K. Evaluation of antioxidant and antimicrobial activity of ficuscarica leaves: An in vitro approach. J. Plant Pathol. Microbiol. 2013, 4, 1-4.

26. Soliva-Fortuny, R.C.; Martín-Belloso, O. New advances in extending the shelf-life of fresh-cut fruits: A review. Trends Food Sci. Technol. 2003, 14, 341-353. [CrossRef]

27. Veronique, C. Bioactive packaging technologies for extended shelf life of meat-based products. Meat Sci. 2008, 78, 90-103.

28. Wang, L.F.; Rhim, J.W. Preparation and application of agar/alginate/collagen ternary blend functional food packaging films. Int. J. Biol. Macromol. 2015, 80, 460-468. [CrossRef] [PubMed]

29. Guerrero, P.; Etxabide, A.; Leceta, I.; Penalba, M.; DelaCaba, K. Extraction of agar from Gelidium sesquipedale (Rodhophyta) and surface characterization of agarbased films. Carbohydr. Polym. 2014, 99, 491-498. [CrossRef] [PubMed]

30. Cristiaen, D.; Bodard, M. Spectroscopic infrarouge de films dagar de Gracilariaverrucosa (Huds.) papenfuss. Bot. Mar. 1983, 26, 425-427.

31. Kanmani, P.; Rhim, J.W. Physical, mechanical and antimicrobial properties of gelatin based active nanocomposite films containing AgNPs and nanoclay. Food Hydrocoll. 2014, 35, 644-652. [CrossRef]

32. Rhim, J.W. Physical-mechanical properties of ager/k-carrageenan blend film and derived clay nanocomposite film. J. Food Sci. 2012, 77, 66-73. [CrossRef] [PubMed]

33. Tako, M.; Higa, M.; Medoruma, K.; Nakasone, Y. A highly methylated agar from red seaweed, gracilaria arcuata. Bot. Mar. 1999, 42, 513-517. [CrossRef]

34. Armisen, R.; Galatas, F. Production, properties and uses of agar. In Production and Utilization of Products from Commercial Seaweeds, FAO Fisheries Technical Paper, 1st ed.; McHugh, D.J., Ed.; Food and Agriculture Organization of the United Nations: Rome, Italy, 1987; pp. 1-57.

35. Gomez-Ordonez, E.; Ruperez, P. FTIR-ATR spectroscopy as a tool for polysaccharide identification in edible brown and red seaweeds. Food Hydrocoll. 2011, 25, 1514-1520. [CrossRef]

36. Reddy, N.; Yang, Y.Q. Citric acid cross-linking of starch films. Food Chem. 2010, 118, 702-711. [CrossRef]

37. Rhim, J.W.; Wang, L.F. Mechanical and water barrier properties of agar/carrageenan/konjacglucomannan ternary blend biohydrogel films. Carbohydr. Polym. 2013, 96, 71-81. [CrossRef] [PubMed]

38. Selke, S.E.M.; Cutler, J.D.; Hernandez, R.J. Plastics Packaging: Properties, Processing, Applications and Regulations, 2nd ed.; Hanser: Munich, Germany, 2004; p. 203.

39. Kanmani, P.; Rhim, J.W. Physicochemical properties of gelatin/silver nanoparticle antimicrobial composite films. Food Chem. 2014, 148, 162-169. [CrossRef] [PubMed]

40. Rhim, J.W.; Wang, L.F.; Hong, S.I. Preparation and characterization of agar/AgNPs composite films with antimicrobial activity. Food Hydrocoll. 2013, 33, 327-335. [CrossRef]

41. Restaino, L.; Komatsu, K.K.; Syracuse, M.J. Effects of acids on potassium sorbate inhibition of food-related microorganisms in culture media. J. Food Sci. 1982, 47, 134-138. [CrossRef]

42. Perdones, Á.; Escriche, I.; Chiralt, A.; Vargas, M. Effect of chitosan-lemon essential oil coatings on volatile profile of strawberries during storage. Food Chem. 2016, 197, 979-986. [CrossRef] [PubMed]

43. Ghafir, S.A.M.; Gadalla, S.O.; Murajei, B.N.; El-Nady, M. Physiological and anatomical comparison between four different apple cultivars under cold-storage conditions. Afr. J. Plant Sci. 2009, 3, 133-138.

44. Jan, I.; Rab, A. Influence of storage duration on physico-chemical changes in fruit of apple cultivars. J. Anim. Plant Sci. 2012, 22, 708-714.

45. Irfan, P.K.; Vanjakshi, V.; Prakash, M.N.K.; Ravi, R.; Kudachikar, V.B. Calcium chloride extends the keeping quality of fig fruit (Ficuscarica L.) during storage and shelf-life. Postharvest Biol. Technol. 2013, 82, 70-75. [CrossRef] 
46. Marpudi, L.S.; Ramachandran, P.; Srividya, N. Aloe vera gel coating for postharvest quality maintenance of fresh fig fruits. Res. J. Pharm. Biol. Chem. Sci. 2013, 4, 878-887.

47. Wang, J.; Chao, Y. Effect of 60 Co irradiation on drying characteristics of apple. J. Food Eng. 2003, 56, 347-351. [CrossRef]

48. Jiang, Y.; Fu, J. Inhibition of polyphenol oxidase and the browning control of litchi fruit by glutathione and citric acid. Food Chem. 1998, 62, 49-52. [CrossRef]

49. Santerre, C.R.; Cash, J.N.; Vannorman, D.J. Ascorbic acid/citric acid combination in the processing of frozen apple slices. J. Food Sci. 1988, 53, 1713-1716. [CrossRef]

50. Nath, A.; Deka, B.C.; Singh, A.; Patel, R.K.; Paul, D.; Misra, L.K.; Ojha, H. Extension of shelf life of pear fruits using different packaging materials. J. Food Sci. Technol. 2012, 49, 556-563. [CrossRef] [PubMed]

51. Goncalves, E.D.; Antunes, P.L.; Brackmann, A. Controlled atmosphere storage of Asian pears CV. Nijisseiki. Rev. Bras. Frutic. 2000, 22, 226-231.

52. Park, Y.M. Relationship between instrumental and sensory analysis of quality factors in apple and pear fruits. Korean J. Hortic. Sci. Technol. 2002, 20, 394-398.

53. Carrillo-Lopez, A.; Cruz-Hernandez, A.; Guevara-Lara, F.; Paredes-Lopez, O. Physico-chemical changes during ripening in storage of two varieties of prickly pear stored at $18{ }^{\circ}$ C. J. Food Sci. Technol. 2003, 40, 461-464.

54. Feng, C.Y.; Wang, W.W.; Ye, J.F.; Li, S.S.; Wu, Q.; Yin, D.D.; Li, B.; Xu, Y.J.; Wang, L.S. Polyphenol profile and antioxidant activity of the fruit and leaf of vacciniumglaucoalbum from the Tibetan Himalayas. Food Chem. 2017, 219, 490-495. [CrossRef] [PubMed]

55. Khatabi, O. Extraction and determination of polyphenols and betalain pigments in the Moroccan prickly pear fruits (Opuntiaficusindica). Arabian J. Chem. 2016, 9, 278-281. [CrossRef]

56. Sheng, L.; Shen, D.; Luo, Y.; Sun, X.; Wang, J.; Luo, T.; Zeng, Y.; Xu, J.; Deng, X.; Cheng, Y. Exogenous $\gamma$-aminobutyric acid treatment affects citrate and amino acid accumulation to improve fruit quality and storage performance of postharvest citrus fruit. Food Chem. 2017, 216, 138-145. [CrossRef] [PubMed]

57. Aguado, A.; Galán, M.; Zhenyukh, O.; Wiggers, G.A.; Roque, F.R.; Redondo, S.; Peçanha, F.; Martín, A.; Fortuño, A.; Cachofeiro, V. Mercury induces proliferation and reduces cell size in vascular smooth musclecells through MAPK, oxidative stress and cyclooxygenase-2 pathways. Toxicol. Appl. Pharm. 2013, 268, 188-200. [CrossRef] [PubMed]

58. Mateos, R.; Lecumberri, E.; Ramos, S.; Goya, L.; Bravo, L. Determination of malondialdehyde (MDA) by high-performance liquid chromatography in serum and liver as a biomarker for oxidative stress: Application to a rat model for hypercholesterolemia and evaluation of the effect of diets rich in phenolic antioxidants from fruits. J. Chromatogr. B 2005, 827, 76-82. 